\title{
Cancer Incidence of Korean Veterans
}

\author{
Un Je Park', So Hee Park ${ }^{2}$ \\ ${ }^{1}$ Department of Medical Record, Seoul Veterans Hospital, Korea Veterans Health Service, Seoul;, Department of Nursing, Daejeon Veterans Hospital, \\ Korea Veterans Health Service, Daejeon, Korea
}

Objectives: The purpose of this study is to understand the rate of cancer incidence in veterans hospitals, which is in charge of care and treatment of Korean veterans, as Korea is accelerating its entry into the aging society. Methods: Cancer incidence data from January 1st 2013 to June 30 th 2016 were obtained from Veterans hospitals in 5 different regions, nationwide. The incidence was defined by the number of cancer patients diagnosed in 2013. We investigated the sociodemographic and clinical characteristics of subjects. CR rates and ASR were calculated. Results: In 2013, 2,070 Korea veterans out of 672,532 were newly diagnosed with cancer which was $0.3 \%$ of the total. Vietnam War veterans showed the highest rate of cancer incidence. Prostate cancer was the most commonly diagnosed cancer and followed by stomach, lung, colorectal and liver cancer. The total CR for overall cancer incidence of veterans was 307.8 and the CR for prostate cancer was the highest (59.2) followed by stomach (51.0), lung (50.6), colorectal (48.2), and liver (22.9). Furthermore, the total ASR rates were 51.1 followed by lung (8.9), prostate cancer (8.8). Conclusions: In 2013, there were 2,070 veterans who were newly diagnosed cancer and over $97.9 \%$ of them were over the age of 60 . Compared to IR for overall cancer incidence of the non-veteran Koreans (52.8\%), the rate of IR of veterans (97.9\%) were 1.8 times higher. Like that, at considering the characteristic of war veterans that elderly population rate is much higher comparing to the whole population in Korea, it is expected that the cancer incidence of war veterans will be continually increased.

Key words: Cancer, Veterans, Incidence rate, Crude rate, Age standardized rates

\section{INTRODUCTION}

The patriots and veterans affairs exists for supporting veterans, patriots and their families who sacrificed for Korea. Therefore, veteran hospitals provide medical and welfare services for patriots, veterans, and their families as public agency.

The Korean Veteran Almanac [1] in 2011 showed the rates of veterans who were above the age 65 was $66.6 \%$. Compared to the standard of aging society defined by United Nations, aging of veterans is serious. The ratio of veterans diagnosed chronic diseases like cancer, diabetes mellitus, hypertension was $28.6 \%$ higher than the $18.4 \%$ for other patients who diagnosed chronic diseases in hospitals for common people.

The number of veterans who were diagnosed with severe diseases like cancer, were keep growing and it took $60 \%$ of care trusts [2]. Both the

\section{Corresponding author: Un Je Park}

53 Jinhwang-ro 61 beon-gil, Gangdong-gu, Seoul 05368, Korea

E-mail: woongbi21c@hanmail.net

Received: January 26, 2018 Revised: April 17, 2018 Accepted: May 8, 2018

No potential conflict of interest relevant to this article was reported. aging and the number of cases diagnosed chronic diseases and cancer of veterans were higher than common people.

The national cancer registration program was launched in 1980 followed by constructing national medical center. Since 2000, after the national cancer center was founded, the national cancer control administration team is in charge. Also, the cancer control act, enacted in 2003, enabled national and regional cancer control administration teams take part in important role in research of national cancer registration and statistics. Cancer incidence of Korea is calculated by data of over 200 hospitals in Korea and data of National Health Insurance Service (NHIS). The ministry of health and welfare collects data of cancer cases, makes DB and publishes annual report of national cancer registration and statistics in Korea.

Recently, aging of veterans is rapidly increasing and we expect cancer

How to cite this article:

Park UJ, Park SH. Cancer incidence of Korean Veterans. J Health Info Stat 2018;43(2):119-125. Doi: https:// doi.org/10.21032/jhis.2018.43.2.119

(cc) It is identical to the Creative Commons Attribution Non-Commercial License (http://creativecommons.org/licenses/by-nc/4.0) whichpermit sunrestricted non-commercial use, distribution, and reproduction in any medium, provided the original work is properly cited.

(c) 2018 Journal of Health Informatics and Statistics 
incidence will also increase. So, in this report, we will figure out annual cancer incidence of veterans. As the cancer incidence in Korea is increased annually, it is expected that super-elderly war veterans' cancer incidence will be increased, so the purpose of this study was to recognize the cancer incidence by identifying the characteristics of veteran cancer patients by age, primary site and veteran type.

We analyzed veterans who diagnosed cancer as follows: Identifying cancer incidence of veterans and figuring out veteran sociodemographic feature and clinical characteristics. Analyzing and comparing common cancer sites, CR, ASR, and SIR among different types of veterans.

\section{METHODS}

\section{Data sources}

The objects of this research are veterans who diagnosed cancer at veteran's hospitals, who diagnosed cancer at common hospitals and re-registered to veteran's hospital for saving costs and who request trusts to other hospitals.

In most cases, if a veteran diagnosed cancer, he would like to visit veterans' hospital for having cost reduction and grading. Veteran hospital managed clients by providing immediate treatments who diagnosed cancer and connecting clients to care trusts who live in long distance from veteran hospitals.

Data of cancer incidence of veterans as follows:

(1) Newly diagnosed cancer statistics in 2013 gained at 5 veterans hospitals.

(2) Incomplete data of cancer suspected cases obtained by national cancer control administration (Statistics of severe disease-cancer cases, nonregistered cancer cases calculated by NHIS).

(3) Nonregistered data of cancer mortality rates in 2013 provided by Statistics Korea.

(4) The data registered in veterans hospitals' program. There are 9 variables-types, ages, regions, first medical examination date, sites, differentiation, diagnosis method, treatment method and SEER code used for analyzing veterans' cancer cases. The cohort of this research is veterans who firstly diagnosed cancer and registered in 2013.

\section{Statistical analysis}

The study subjects are veterans who were newly diagnosed with can- cers in 2013 and also including late-registered cases from January 1st, 2013 to June 30th, 2013. The investigation period is 6 months from July 1st to December 31st, 2016.

When there is a case that has multiple primary cancers, it contained respectively as registered in national cancer registration and statistics. The total number of veterans diagnosed cancer were obtained from 5 veterans hospitals' electrical medical records, data bases and programs that contained veterans' personal information like names, resident registration number, disease information.

Rates were expressed as crude ratio (CR) per 100,000 individuals. The crude rate was calculated as the total number of incidence cases divided by the total number of veterans of the specified year. The age standardized rate (ASR) was weighted average calculated by rates of standard population of each age groups.

Moreover, the standardized incidence rates were calculated as the sums of the previous SIR divided by the sum of the expected SIR. Confidence interval (CI) above 1.0 were considered statistically significant. SPSS 23.0 (IBM Co., Armonk, NY, USA) were used to calculate the incidence and to perform the statistical analyses.

\section{RESULTS}

\section{The cancer incidence by types and diagnosis methods}

In 2013, a total of 2,070 veterans were newly diagnosed with cancer during the investigation period (Table 1). The Vietnam War veterans took the largest part (56.3\%) followed by the Korean War (30.7\%), Disabled Veterans (9.3\%), National Merit guardian (3.0\%), Public officials (0.5\%) and Discharged veterans (0.2\%). In 2013, 2,070 Korea veterans out of 672,532 were newly diagnosed with cancer which was $0.3 \%$ of the total. Vietnam War veterans showed the highest rate of cancer incidence.

There are 4 variables when analyzed by ages. The average age of veterans who diagnosed with cancer was 72.5 , age between 60 and 69 was $47 \%$, between 70 and 79 was $19.9 \%$ and age above 80 was $31 \%$ of total. Age above 60 accounted for $97.9 \%$.

Considered region, veterans who live in Seoul and Gyeong-gi were 48.1\%, followed by Gwangju/Jeolla Namdo/Bukdo (13.8\%), and Busan (13.0\%). Prostate cancer (19.2\%) was the most common cancer in veterans, followed by stomach (16.6\%), lung (16.4\%), colorectal (15.7\%), and liver (7.4\%). 
Table 1. The cancer incidence by veterans and methods of cancer treatments

\begin{tabular}{|c|c|c|c|}
\hline Characteristics & n (\%) & Characteristics & n (\%) \\
\hline Veterans types & & Veterans types & (cancer) \\
\hline Disabled veterans & $192(9.3)$ & Disabled veterans & $118,076(192)$ \\
\hline Vietnam veterans & $1,165(56.3)$ & Vietnam veterans & $260,494(1,165)$ \\
\hline Public officials & $11(0.5)$ & Public officials & 4,787 (11) \\
\hline 6.25War veterans & $637(30.7)$ & 6.25 War veterans & $167,857(637)$ \\
\hline $\begin{array}{l}\text { National Merit } \\
\text { guardian }\end{array}$ & $64(3.0)$ & $\begin{array}{l}\text { National } \\
\text { Merit guardian }\end{array}$ & $64,480(64)$ \\
\hline \multirow{2}{*}{$\begin{array}{l}\text { Long-term } \\
\text { veterans }\end{array}$} & $4(0.2)$ & Long-term veterans & $56,838(4)$ \\
\hline & & Total & $672,532(2,070)$ \\
\hline Age (y) & & Diagnosis method & \\
\hline$<60$ & $44(2.1)$ & Clinical only & $120(5.9)$ \\
\hline $60-69$ & $973(47.0)$ & $\begin{array}{l}\text { Clinical } \\
\text { investigations }\end{array}$ & $249(12.1)$ \\
\hline $70-79$ & $412(19.9)$ & $\begin{array}{l}\text { Histology of } \\
\text { primary }\end{array}$ & $1,627(79.7)$ \\
\hline \multirow[t]{2}{*}{$\geq 80$} & $641(31.0)$ & $\begin{array}{r}\text { Histology of } \\
\text { metastasis }\end{array}$ & $47(2.3)$ \\
\hline & & $\begin{array}{l}\text { Cytology or } \\
\text { hematology etc. }\end{array}$ & $27(1.3)$ \\
\hline Primary site & & By region & \\
\hline 1. Prostate & $398(19.2)$ & Seoul·Gyeonggi & $995(48.1)$ \\
\hline 2. Stomach & $343(16.6)$ & Incheon & $65(3.1)$ \\
\hline 3. Lung & $340(16.4)$ & Gangwon & $42(2.0)$ \\
\hline 4. Colon · ructum & $324(15.7)$ & Busan·Gyeongnam & $269(13.0)$ \\
\hline 5. Liver & $154(7.4)$ & Daegu · Gyeongbuk & $251(12.2)$ \\
\hline 6. Bladder & $107(5.2)$ & Gwangju·Jeolla & $286(13.8)$ \\
\hline 7. Pancreas & $57(2.7)$ & Daejeon.Chungcheong & $162(7.8)$ \\
\hline 8. Thyroid & $42(2.0)$ & Total & $2,070(100.0)$ \\
\hline 9. Esophagus & $40(1.9)$ & & \\
\hline 10. Myeloma & $33(1.6)$ & & \\
\hline Total & $2,070(100.0)$ & & \\
\hline
\end{tabular}

\section{Number of cancer cases and cancer incidence rate among} veterans

This table shows incidence rates by cancer sites and number of cases Table 2. The most common cancer site was prostate (19.2\%) followed by stomach cancer (16.6\%), lung (16.4\%), and colorectal (15.7\%). The incidence rate of veterans calculated by standard population was 51.1 per 100,000 , followed by stomach $(8.9 \%)$, prostate $(8.8 \%)$, colorectal $(7.8 \%)$, and lung cancer (6.0\%).

\section{The crude and standardized cancer incidences by cancer sites}

Considering types and sites, the Vietnam War veterans (56.3\%) raked the highest and the most commonly diagnosed cancer type was prostate cancer (20.9\%, CR 36.1), followed by colorectal (17.2\%, CR 29.7), stomach (16.5\% CR 28.6), lung (13.4\%, CR 23.2), and liver (6.9\%, CR 12.0).

The Korean War veterans $(637,30.7 \%)$ hold the second rank, the most common cancer site was lung (22.1\%, CR 30.0), followed by prostate (16.6\%), stomach (14.7\%), colorectal (13.2\%), and liver (8.3\%). Disabled Veterans were $9.3 \%$ of total, the most common cancer was stomach (22.4\%), followed by prostate (16.2\%), lung (15.1\%), colorectal (13.5\%), and liver (8.3\%). Next, National Merit Veterans were 3.0\% of total, lung cancer (20.3\%) was the most common cancer, followed by colorectal (20.3\%), prostate (18.8\%), stomach (17.2\%), and bladder (6.7\%) (Table 3). Among types of veterans, public officials and discharged soldiers were not considered because of low number of cases.

Table 2. Number of cancer cases and cancer incidence rate among veterans, 2013 (per 100,000 persons, per year)

\begin{tabular}{|c|c|c|c|c|c|c|c|}
\hline \multirow{2}{*}{ Characteristics } & \multicolumn{4}{|c|}{ Number of cases by age group } & \multirow{2}{*}{ Total (\%) } & \multirow{2}{*}{$\begin{array}{l}\text { Incidence } \\
\text { rate crude }\end{array}$} & \multirow{2}{*}{$\mathrm{ASR}^{1}$} \\
\hline & $<60$ & $60-69$ & $70-79$ & $\geq 80$ & & & \\
\hline All site & 44 & 973 & 412 & 641 & $2,070(100.0)$ & 307.8 & 51.1 \\
\hline Prostate & 3 & 190 & 108 & 97 & $398(19.2)$ & 59.2 & 8.8 \\
\hline Stomach & 12 & 174 & 57 & 100 & $343(16.6)$ & 51.0 & 8.9 \\
\hline Lung & 5 & 131 & 62 & 142 & $340(16.4)$ & 50.6 & 6.0 \\
\hline Colon \& rectum & 8 & 160 & 67 & 89 & $324(15.7)$ & 48.2 & 7.8 \\
\hline Liver & 2 & 78 & 21 & 53 & $154(7.4)$ & 22.9 & 3.1 \\
\hline Bladder & 1 & 48 & 23 & 35 & $107(5.2)$ & 15.9 & 2.6 \\
\hline Pancreas & & 27 & 8 & 22 & $57(2.7)$ & 8.5 & 1.0 \\
\hline Thyroid & 3 & 28 & 9 & 2 & $42(2.0)$ & 6.2 & 2.1 \\
\hline Esophagus & 1 & 18 & 6 & 15 & $40(1.9)$ & 5.9 & 0.9 \\
\hline Myeloma & 3 & 12 & 7 & 11 & $33(1.6)$ & 5.8 & 1.9 \\
\hline
\end{tabular}

${ }^{1} \mathrm{ASR}$, age standardized rate (Korea; 2000 mid-year population). 
Table 3. The crude and standardized cancer incidences by cancer sites

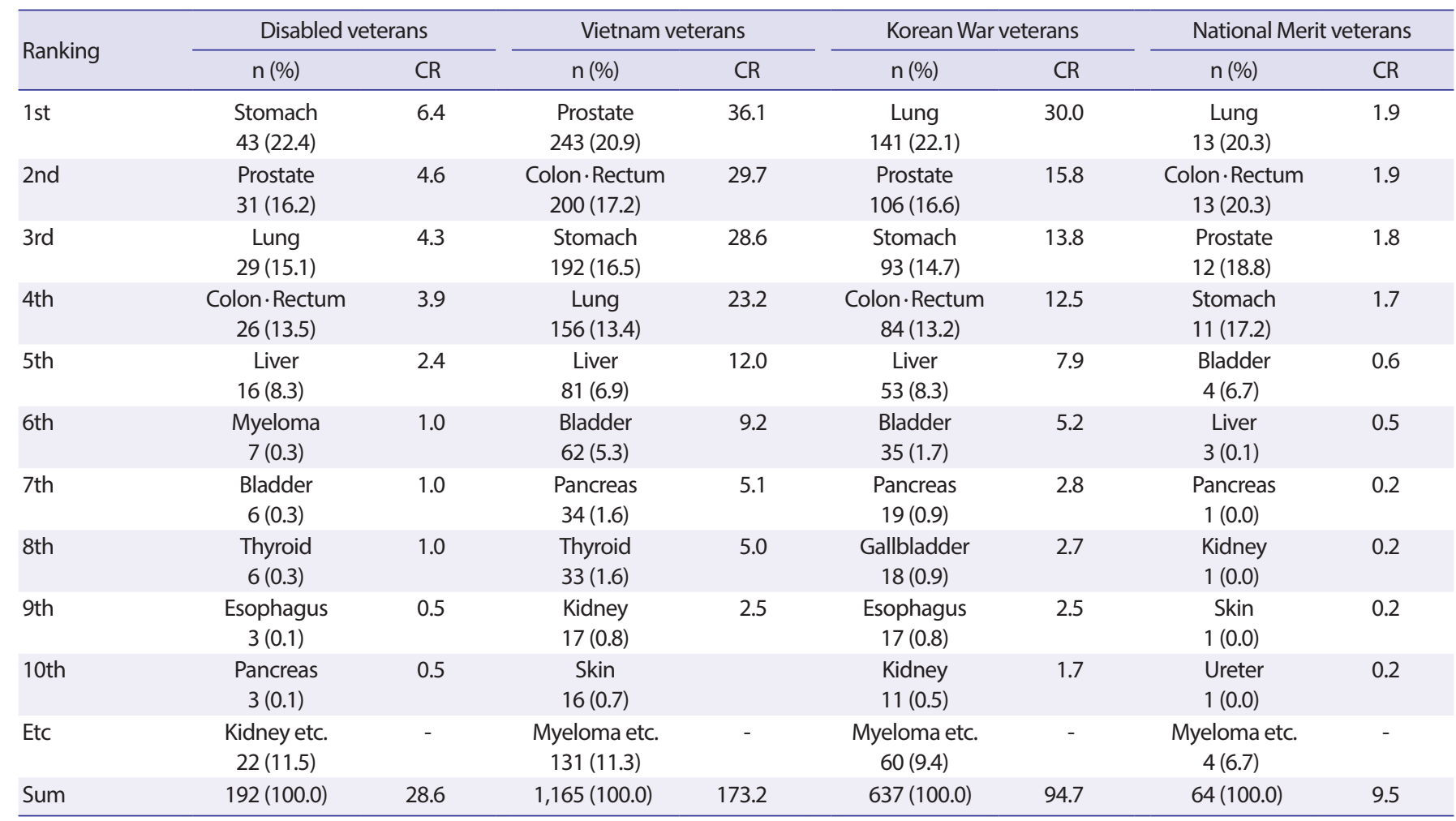

$\mathrm{CR}$, crude ratio.

Crude rates were expressed as crude ratio (CR) per 100,000 individuals.

\section{Comparison the crude rates and standardized incidence} rates between veterans and ordinary Korean by primary

\section{cancer site}

CR of veterans' primary cancer site was 307.8, lower than 445.7 of CR of common Koreans in 2013 (Table 4). Prostate cancer (59.2) was the most common primary site, followed by stomach (51.0), lung (50.6), colorectal (48.2), and liver (22.9). Compared to CR of common Korean male, stomach cancer (59.7) was the highest, followed by colon \& rectum (54.6), lung (45.8), liver (32.0), prostate (18.8), the CR of veterans were lower. The SIR of veterans was 0.7 (95\% CI, 0.6-0.8) and it also showed lower than SIR of the ordinary Koreans.

Especially, veterans' cancer incidence of stomach, colon \& rectum, liver, pancreas, thyroid and gallbladder cancer showed lower than common subjects. However, prostate cancer (3.2), followed by bladder (2.1), esophagus (1.3), and lung (1.1) were statistically higher in veterans.

\section{DISCUSSION}

There are many factors that affect to cancer incidence like environ-
Table 4. Comparison the crude and standardized cancer incidences by cancer sites between veterans and ordinary Koreans

\begin{tabular}{lrccc}
\hline Characteristics & Veterans CR & $\begin{array}{c}\text { Ordinary } \\
\text { people CR }\end{array}$ & SIR & $95 \% \mathrm{Cl}$ \\
\hline All site & 307.8 & 445.7 & 0.7 & $0.6-0.8$ \\
Prostate & 59.2 & 18.8 & 3.2 & $3.0-3.4$ \\
Stomach & 51.0 & 59.7 & 0.9 & $0.7-1.0$ \\
Lung & 50.6 & 45.8 & 1.1 & $1.0-1.3$ \\
Colon \& rectum & 48.2 & 54.6 & 0.9 & $0.8-1.0$ \\
Liver & 22.9 & 32.0 & 0.7 & $0.5-0.8$ \\
Bladder & 15.9 & 7.4 & 2.1 & $1.9-2.2$ \\
Pancreas & 8.5 & 10.9 & 0.8 & $0.7-0.9$ \\
Thyroid & 6.2 & 84.1 & 0.1 & $0.0-0.3$ \\
Esophagus & 5.9 & 4.7 & 1.3 & $1.1-1.4$ \\
Myeloma & 5.8 & 10.4 & 0.6 & $0.5-0.8$ \\
\hline
\end{tabular}

$\mathrm{CR}$, crude rate; $\mathrm{SIR}$, standardized incidence ratio; $\mathrm{Cl}$, confidence interval. ${ }^{1}$ Ordinary people CR: Annual report of cancer statistics in Korea in 2013, Ministry of Health and Welfare, 2015.

ment, region, sex, etc. In 2013, the most common cancers in Korean men were stomach, followed by colorectal, lung, liver, and prostate. In case of Korean women, thyroid cancer was the most, and then breast, colorectal, stomach, and lung cancer was common [3]. 
In $2013,5,280$ veterans out of 672,532 (the total number of veterans) were diagnosed with cancer. Moreover, veterans newly diagnosed with cancer are 2,070 and it took $0.3 \%$ of total. Among the veterans who diagnosed with cancer $(5,280)$, the newly diagnosed cases were $39.2 \%$.

This report chiefly managing about cancer in male veterans because male veterans were $99.9 \%$ of total. There are only 2 women veterans $(0.01 \%)$.

The most common type of veterans who diagnosed with cancer was Vietnam War veterans (56.3\%). The average age of veterans who diagnosed with cancer is 72.5 and Vietnam War veterans are between 60 and 80 so that's why they showed the highest rate of cancer incidence. Furthermore, considering average age of Korean male is 78 [4], high portion of Vietnam War veterans makes sense.

When it comes to age, in 2013 among Korean who diagnosed with cancer, $52.8 \%$ was age over 60 and $8.9 \%$ was age over 80 [5]. In case of veterans who diagnosed with cancer, age over 60 (97.9\%) and age over 80 (31.0\%). It shows aging in veterans are more rapidly increasing.

The most reported cancer site in veterans is prostate (19.2\%), and also it is the most common cancer in Vietnam War veterans. The reason why prostate cancer is mainly showed in Vietnam War veterans is the herbicide used in Vietnam War. According to Veterans and Agent Orange [6], herbicides like Agent Green and Agent Orange are closely related to incidence of prostate, lung cancer and non-Hodgkin lymphomas.

The most common diagnosed cancer in Korean men 2013, was stomach cancer (17.8\%) followed by colorectal cancer (14.6\%), lung (14.2\%), liver (10.6\%) and prostate (8.4\%). There is little difference in common cancer between whole Korean men and Korean veterans. According to annual report of national cancer registration and statistics in Korea, the most common cancers in OECD were prostate, colorectal and lung cancer. The result was similar with Korea, except stomach cancer was the most common in Korean.

According to cohort research in 2011, reported by Korea Occupational Safety and Health Agency [7], the most common cancer in workers was stomach (24.2\%), followed by liver (17.0\%), lung (10.6\%), thyroid (4.4\%), and non-Hodgkin lymphoma (2.8\%). There is some difference in sites and ranks in case of veterans.

In analysis of CR of veterans, in 2013 [5], CR of Korean veterans who were diagnosed with cancer was 307.8. It was lower than CR of cancer case in annual report of national cancer registration and statistics (445.7) and in report of Yi [8] (431.6). However, CR of Korean veterans' cancer incidence was higher than Korean workers (187.4) reported by Korea Occupational Safety and Health Agency. Prostate cancer, the most common in veterans, CR of veterans was 59.2 per 10, and it is higher than CR of prostate cancer in common Korean (18.8) and of Yi's [8] report (6.0).

The ASR of veterans in 2013 considering standard population was 51.1 per 100,000. The most common cancer was stomach (8.9) followed by prostate (8.8). When it comes to comparing the ASR of Koreans in 2013, the ASR was 311.6 per 100,000, followed by thyroid (71.3) and lung (38.9).

Comparing SIR between veterans diagnosed with cancer and ordinary Korean cancer patients, cancer SIR of veterans were 0.7, lower than ordinary Korean cancer patients. However, prostate cancer was 3.2 times higher in veterans, followed by bladder (2.1), esophagus (1.3), and lung (1.1). In contrast, cancer incidence of veterans were 3.2 times higher than ordinary Korean followed by bladder (2.1), esophagus (1.3), and lung cancer (1.1). SIR of Korean air force officials reported by Lim [9] was 0.2, higher than SIR of veterans and most of incidence rates of cancer sites were higher than air force officials. In case of cancer incidence of Vietnam War veterans reported by Yi [8], the cancer SIR of Vietnam War veterans 0.97 and it is lower than veterans. The SIRs of Vietnam War veterans were prostate (1.2), lung (1.0) and esophagus cancer (0.7) which was lower than veterans'. The report of cancer incidence in Ganghwa region by Lee [10], SIR of the regions were stomach (1.2), lung (1.4), liver (1.3) compared to SIR of veterans-stomach (0.9), lung (1.1), liver (0.7). The result shows SIR of veterans was lower.

\section{CONCLUSION}

In conclusion, in 2013, there were newly diagnosed cancer patients were 2,070 out of 672,532 veterans, and the most common type of veterans who diagnosed with cancer was Vietnam War veterans (56.3\%). The most common site of cancer was prostate (19.2\%) and it is different from the most common cancer in ordinary Koreans-stomach cancer. The veterans, age over 60 , was $97.9 \%$ of total. The aging of veterans is rapidly increasing and it is one of the major cause of increasing cancer incidence. The cancer incidence rate of most common cancer of veterans per 100,000 was 51.1, the most common cancer was stomach cancer(8.9), followed by prostate cancer (8.8).

This report analyzed the common site of cancer, CR, ASR, of veterans 
who were diagnosed with cancer. Therefore, I hope this study helps to encourage early diagnosis and prompt treatment for the elderly veterans and those who have experienced exposure to the local environment, which may have a significant impact on cancer development due to war.

This report is the first report of analyzing about cancer incidence of Korean veterans. The period of this study is about a year and it is the limitation of this study.

\section{REFERENCES}

1. Ministry of Patriots and Veterans Affairs. Veterans yearbook, 20112014. p. 119-140 (Korean).

2. Kim Y, Kim SJ, Park UJ. Development plan of Veterans Affairs Medical Center in consideration the specificity of the Veterans Hospital Patients. Korea Veterans Health Service, Daejeon Veterans Hospital. 2003, p. 3-37 (Korean).

3. National Cancer Control Institute. National cancer registration and statistics in Korea 2008-2014. Goyang: National Cancer Control Institute; 2010-2016 (Korean).

4. Ministry of Patriots and Veterans Affairs. Available at http://www. mpva.go.kr/info [accessed on 18 October 2016].

5. National Cancer Control Institute. National cancer registration and statistics in Korea 2013. Goyang: National Cancer Control Institute; 2015 (Korean).

6. Veterans and Agent Orange, update 2010. Washington, DC: National Academy Press, Institute of Medicine; 2011, p. 7-10, 54-59.

7. Occupational Safety and Health Research Institute. Establish age-based, sex, mortality and cancer incidence data for workers across the country. Incheon: Occupational Safety and Health Research Institute; 2011 (Korean).

8. Yi SW. Cancer incidence in Korean Vietnam veterans during 19922003: The Korean veterans health study. J Prev Med Public Health 2013;46:309-318 (Korean).

9. Lim JG. Korea air force public worker cancer incidence survey. J Korean Soc Aviat Aeronaut 2011;19(4):99-104 (Korean).

10. Lee SC, Lee KH, Kim HS, Lee SH, Choi TH, Park YJ, et al. The comparative study of cancer incidence between urban and rural area in Gangneung: gastric cancer, hepatoma and lung cancer. The Korean J Med 2005;68:(1):66-75 (Korean).

11. Choi PG. Development direction of Korean Veterans' system. Seminar on Korean Veterans Society. 2002, p. 89 (Korean).

12. Estimated cancer incidence rate for 2012 using the cancer registration data by the year 2007. GLOBOCAN 2012, IARC, 2013.

13. Ferlay J, Soerjomataram I, Ervik M, Dikshit R, Eser S, Mathers C, et al. GLOBOCAN 2012 v1.0. Cancer incidence and mortality worldwide: IARC Cancer Base No. 11 [Internet]. Lyon: International Agency for Research on Cancer; 2013. Available at www.globocan.iarc.fr [accessed on January 28, 2016].

14. Jung KW, Won YJ, Kong HJ, Oh CM, Cho H, Lee DH, et al. Cancer statistics in Korea: incidence, mortality, survival, and prevalence in 2012. Cancer Res Treat 2015;47:127-141 (Korean).

15. Statistics Korea. Available at http://kosis.kr [accessed on January 28, 2015]. 


\section{국문초록}

\section{한국 보훈대상자의 암발생률}

박운제·박소희

목적: 한국의 초고령화 사회로의 진입이 가속화됨에 따라 고령자가 많은 국가 보훈대상자의 진료 및 치료를 담당하는 보훈병원 내의 암 환자 수가 더욱 증가할 것으로 예상되어 우리나라 보훈대상자의 암 발생률을 파악하고자 한다.

방법: 전국 5개의 보훈병원에서 2013년 1월 1일부터 2016년 6월 30일까지의 자료를 바탕으로 2013년도 초진 암발생 환자의 의무기록 자 료를 조사하였다. 보훈대상자 암환자의 인구사회학적 특성, 임상적 특성을 규명하고 조발생률 및 연령표준화발생률을 구하였다.

결과: 2013 년 우리나라 보훈대상자 672,532 명 중에서 초진 암환자는 2,070 명으로 전체 보훈대상자 중 $0.3 \%$ 를 차지하였으며, 보훈대상자 유형별로는 베트남참전유공자가 가장 많았다. 호발 암 원발 부위별로는 전립샘암이 가장 많았고, 다음은 위암, 폐암, 대장. 직장암, 간암 순으로 발생하였다. 보훈대상자의 암발생률에서 조발생률은 307.8명이었으며, 전립샘암이 59.2명으로 가장 많았고, 위암 51.0명, 폐암 50.6 명, 대장. 직장암 48.2 명, 간암이 22.9 명으로 뒤를 이었으며, 연령표준화발생률은 인구 10 만 명당 51.1 명, 위암 8.9 명, 전립샘암 8.8 명이 었다.

결론: 2013년 보훈대상자 초진 암환자는 2,070명으로 그 중 60세 이상이 97.9\%로서 우리나라 일반국민 암환자 60세 이상의 $52.8 \%$ 보다 암 발생률이 약 1.8 배 높았다. 이와 같이 우리나라 전체 국민보다 고령 인구의 비율이 훨씬 높은 보훈대상자들의 특성을 고려했을 때 보 훈대상자들의 향후 암발생률이 지속적으로 증가할 것으로 예상한다.

주제어: 암, 보훈대상자, 발생률, 조발생률, 연령표준화발생률 